\title{
Between Islam and the nation; nation-building, the ulama and Alevi identity in Turkey
}

ABSTRACT. This article analyses the relationship between Islam and nationalism by considering the role of the ulama in Turkey, housed within the Presidency of Religious Affairs (PRA). The ulama religious scholars and experts of Islamic law - in Muslim majority contexts are typically closely linked with the state and play a key role in shaping the boundaries of Islam and of what is Islamically acceptable. However, this is also of consequence for the boundaries of the nation, since in Turkey Islam and nationalism has been intertwined, with Islam playing a central role in nation-building, as a basis of ethnic identity formation and a source of symbols and myths. This articles shows, firstly, that the PRA has acted as a carrier and preserver of Sunni (Hanefi) Muslim identity in continuity with the Ottoman ulama and, secondly, that it has delimited nation-building, by considering its approach to and interventions against Alevi identity.

KEYWORDS: Alevis, institutions, Islam, nationalism, nation-building, Turkey, ulama

\section{Introduction}

In January 2016, the head of Turkey's top religious authority, the Presidency of Religious Affairs (Diyanet İşleri Başkanlığı, PRA), a prominent institution within the Republic, reiterated the body's long-standing objection to the official recognition of cemevis, the places of worship of Alevis.1 The Alevis comprise the second largest faith community after Sunni Muslims in Turkey, estimated at fifteen to twenty-five per cent of the population of Turkey (Erdemir 2005: 938). The matter of how to approach Alevi identity is highly contested; it has been considered through ethnic, cultural, political and religious terms, as within and outside Islam and as ethnically Turkish or Kurdish.2 The legal recognition of cemevis has been a key demand of Alevis seeking equal citizenship and access to state resources as enjoyed by (Sunni) Muslims and mosques.3 However, in his rejection of the promises of recognition made by the Islamist Justice and Development Party (Adalet ve Kalkınma Partisi, AKP) government, the head of the PRA emphasised 'two red lines' for the state body; 'One of them is defining Alevism as a path separate from Islam, since its 1,000-year-old history refutes this claim. The second is presenting cemevis as an alternative to mosques and as the place of worship of another belief' (Hurriyet Daily News 2016).

In general, the push for legal recognition of cemevis and Alevi demands have largely been considered as a matter of religious freedom and with reference to the nature and limits of Turkish secularism, while the PRA's position has been regarded as pertaining only to Islamic interpretation. The PRA, widely acknowledged as a Sunni Hanefi4 Muslim religious authority, houses the Turkish (official) ulama religious scholars and experts of Islamic law. The state body was established in 1924 in place of the Ministry of Shari'a and Foundations, which itself was instituted in 1920 by the nationalist government in Ankara in place of the Ottoman office of the Şeyhülislam, the chief Islamic authority. Within Muslim majority contexts, the ulama are typically closely associated or integrated within the state apparatus as institutions of Islamic authority, playing a fundamental role in shaping and defining Islamic law and upholding the social order. They are both the guardians of tradition, as the protectors of Islamic learning, and act as the custodians of change as this learning is transmitted through the generations (Zaman 2010). In Turkey, the PRA is legally tasked with carrying out 'affairs related to the beliefs, worship and moral foundations of Islam, and to enlighten Turkish society about religion and to manage places of worship': it has a monopoly on overseeing religious life. Since its establishment, its influence and remit has grown together with its size; according to official statistics, in 2014 it comprised around 120,000 personnel and oversaw over 86,000 mosques.

Yet the PRA's statements on the Alevis do not only concern religious doctrine and what is Islamically acceptable. The discussion here demonstrates that in shaping the bounds of Islam, analysed through the approach to Alevism, the PRA also has a bearing on the boundaries of the national community. This article argues that this is owing to two dynamics that relate to the relationship between religion and nationalism. Firstly, as a rich 'symbolic resource' (Zimmer 2003) facilitating ethnic formation and Turkish nation-building, Islam has been intertwined with Turkish national identity. Secondly, religion, considered here as an institutional site rather than a 'disembodied belief system' (Sidel 2007), has acted 
as a carrier of identity, underpinning the persistence of Sunni (Hanefi) Muslim group boundaries. Accordingly, the conflation between Islam and nation means that the PRA's approach to Alevism is consequential for the parameters of inclusion and exclusion of Turkish national identity. Despite this, the role of Islamic authority, the ulama, in relation to nationalism, remains understudied, particularly in the Turkish context. In part, this neglect is the result of the commonplace approaches that regarded the ulama as marginalised and confined to the mosques and madrasas (religious schools) following the establishment of the modern nation-state (Hatina 2009). In recent years, there has been increasing recognition that the ulama have been more active and influential in the modern period than previously thought, but the focus of these studies has chiefly been on religious life and secularism. In the Turkish case, there has been a greater neglect of the role of the ulama despite various studies demonstrating a close link between Turkish nationalism Islam and the state. This has reflected the prevalent tendency to regard Turkey as a paradigmatic example of a secular nation-state project led by a positivist and anticlerical nationalist elite, with the PRA characterised within this narrative as a passive and submissive ideological apparatus of the ostensibly secular state (Gözaydın 2014; Kara 2008). It was indeed the case that the secularisation of the legal system following the establishment of the Republic narrowed the domain of the ulama, relative to its more extensive role in the Ottoman Empire, and compared with other modern majority Muslim states, where Islamic law is incorporated within their constitutions. Likewise, the abandonment of the word ulama by the early Republican regime by the 1930s (Bein 2011) reinforced this perception of a break with the Ottoman past.

However, contrary to these approaches, and based on both archival research and the analysis of official PRA publications, I not only outline the lines of continuity between the Ottoman and Republican periods but also stress the agency of the PRA with respect to Turkish national identity. The article proceeds firstly by reviewing the relationship between religion and nationalism. In order to contextualise the PRA's stance on Alevism, the second section considers the contested relationship between Turkish nationalism and Alevism, with Alevi identity utilised in the process of national identity construction but at the same time consigned to 'invisibility' (Zırh 2012) and treated as an internal enemy by the Turkish state. The following section outlines two crucial ways in which the PRA shapes the boundaries of the national community. Firstly, how the PRA has acted as a carrier and preserver of Sunni (Hanefi) Muslim identity is demonstrated through an analysis of its interventions against and efforts to shape Alevism. This role, it is argued, has parallels with the office of Şeyhülislam in the late Ottoman Empire and the Hamidian (1876-1909) project of imagining and constructing a Sunni Muslim 'social base' (Deringil 1998), suggesting areas of continuity between the Ottoman and Republican periods. Secondly, the PRA is able to negotiate national boundaries on the basis of its position as a religious authority with its own agenda, resisting efforts and policies by other state actors such as the military5 regarding Alevism.

The final section concludes with a discussion on the questions raised by the PRA case study. Given its position as a key institutional site of Islam, the PRA's role relates to a wider question regarding the relationship between Islam and nationalism or more generally religion and nationalism. The extent to which Islam's idea of the political community is compatible with the nation-state (Zubaida 2004) has been an area of ongoing debate. Various scholars have suggested that despite the universalist, transnational or pan-Islamic reasoning of Islamic thought, in practice there has been a reconciliation with the nation-state (Aspinall 2007; Zubaida 2004). The ulama's approach towards Alevism suggests a tension between the Islamisation agenda of the PRA as a Sunni Muslim religious authority and the nation-state that can transcend the delineation of the community as the religious majority. However, given the intertwined nature of Islam and nation, determining whether the PRA is simply accommodating the nation-state within its religious framework or subjecting religion to the nation-state remains a difficult task. Instead, the case of the PRA suggests that a fruitful way of approaching the relationship between the Turkish nation and Islam is to see them as distinct but analogous phenomena, sharing an 'overlapping consensus' (Rawls 1987) on establishing a homogenous Sunni Muslim-Turkish political union. However, this study also demonstrates the ways in which institutions, in further facilitating the hardening of community boundaries and underpinning their persistence over time, can delimit the processes of nation-building. 


\section{Religion, nationalism and the ulama}

Within nationalism studies, the relationship between religion and nationalism is a matter of contention. Particularly amongst the early modernist scholars, a 'secularist bias' reflecting the prevalence of the modernisation paradigm had involved a tendency to regard nationalism as a modern and secular ideology that had replaced religion (Kedourie 1993; Mihelj 2007; Smith 2003; Van der Veer 1994). Since the 'religious resurgence' in the 1970s and the growing critique of the secularisation thesis, there has been greater acknowledgement over the ways religion can contribute to the origins and development of nationalism or can be intertwined with it (Brubaker 2012; Mihelj 2007; Smith 2003). In this vein, scholars of nationalism have pointed to the ways in which religion offers a rich symbolic repertoire of myths, metaphors and symbols, which can be used as building blocks in the process of national identity construction (Asad 1999; Brubaker 2012; Smith 2003). For some, these dynamics can give nationalism a religious-like quality in which the nation is characterised as a 'sacred communion' (Smith 2003).

Yet, aside from its role as a rich 'symbolic resource' (Zimmer 2003) for nationalism, religion should also be considered as a 'field structured by its own institutions, authority relations, instilled dispositions (habitus) and means of production, accumulation and representation' (Sidel 2007). Consequently, religion can prove a resilient container for the cultural preservation of an ethnic group, since religious groups possess formal organisational bodies that contrast with loosely organised ethnic groups (Conversi 1999). In this vein, religion can become an 'ethnic marker' (Zubaida 1993), in delineating the boundaries of the nation and in involving a subjective belief in common descent. It can be argued therefore that in the case of Turkey as well as in other Muslim contexts, Islam is not just intertwined with nationalism in providing a rich 'symbolic resource' that contributes to ethnic formation but also a carrier of identity.

To further clarify the PRA's role as an institutional site of Islam, it is helpful to elaborate here on two key functions of institutions with respect to national identity. Firstly, institutions can act as 'carriers and preservers of collective identities' (Smith 1998; Hutchinson 2004; Özkırıml 2000: 184-5) which underpin their persistence, as, through them, 'individuals are united into social groups that can perpetuate themselves down the generations' (Smith 1998: 69; Özkırımlı 2000: 184-5). This is not to suggest however that identities are primordial and unchanging; the 'cultural stuff' or the content of identity can change and transform over time, even if this may be limited by the menu of symbolic resources (Kaufmann 2008; Zimmer 2003). But, as Barth (1969: 14) has argued, it is the boundary, 'the fact of continuing dichotomization between members and outsiders, which allows us to specify the nature of continuity'. It is institutions that play a key role in the processes of 'social closure' that underpin the persistence of these identity boundaries over time. Here social closure refers to the process through which certain groups 'establish and maintain their status' and form barriers to entry for the 'participation of certain outsiders' (Wimmer 1997). In other words, the dynamics of institutions can reenforce 'social closure' that locks in the privileges of the constructed majority bloc and thereby can lead to resistance against the processes of 'absorption' (Williams 1989) by 'marginal elements'. How the Turkish ulama frames national identity as Sunni Muslim and resists the 'absorption' of Alevism will be discussed below.

Secondly, institutions are crucially involved in the construction, reproduction and negotiation of national identity, thereby shaping the contours of the nation-state. State institutions in particular, such as the PRA, are uniquely positioned to build and affect the construction of ethnic categories by acting as a differentiating force that distributes privileges and resources amongst groups (Brass 1985). As described by Bourdieu et al. (1994: 7-8): 'through classificational systems ... inscribed in law, through bureaucratic procedures, educational structures and social rituals ..., the state moulds mental structures and imposes common principles of vision and division .... And it thereby contributes to the construction of what is commonly designated as national identity'.

It can be argued therefore that institutions underpin the persistence of identity boundaries, while the content and criteria of inclusion and exclusion are subject to ongoing negotiation and change. It is in this sense that national identity should be conceived of as an ongoing process of construction of the 
nation, rather than a final fixed result (Hutchinson 2004). Likewise, just as the state can be considered as an arena of struggle of different power centres (Jessop 1990), nations are not a 'cohesive collective subject' but rather sites where 'different representations of the nation contest and negotiate with each other' Duara (1996: 8). Indeed, Hutchinson (2004) has described nations as 'zones of conflict' in which competing conceptions of the nation based on multiple heritages, historical cleavages and legacies that 'become systemized into competing cultural and political projects'. From one perspective, the PRA, Turkey's ulama: between Islam and the nation while not a monolithic entity itself, can be considered as a highly influential actor (amongst others) with its own political project. The extent to which there is a tension between its vision of the community and the nation is discussed below.

\section{Turkish nationalism, Islam and the Alevis}

Before the examination of the PRA's approach to Alevism, a discussion of Turkish nation-building, the role of Islam and their relationship to Alevi identity is helpful. The Turkish nation-building project was fundamentally shaped by the legacy of the Ottoman Empire as a multi-ethnic and multi-religious polity where Islam was a crucial reference point; Muslims were positioned at the top and ruled the lands within the hierarchical social structure. In particular, 'ethnic segmentation' (Göçek 1993) under the millet system comprised religiously defined (non-Muslims recognised by Islam as 'people of the book') communities enjoying a degree of administrative and religious autonomy. The polarisation of ethnic segmentation owing to war, imperial penetration and modernisation re-enforced religion as an ethnic marker, shaping the boundaries of the nascent Turkish nation in the sense that it involved the construction and elevation of a Sunni Muslim-Turkish identity.

There are numerous examples of the constitutive role of Islam in Turkish nation- building (Çağaptay 2006; Can and Bora 2004; Çetinsaya 1999; Kirişci 2000), from the use of religion as a criterion in the exchange of populations with Greece in the 1920s to the discriminatory tax laws against non-Muslims adopted in 1942. Indeed, for the founders of Turkish nationalism, there was no contradiction between Islam and the Turkish nation, as illustrated by prominent nationalist Ziya Gökalp's statement, 'I belong to the Turkish nation, Islamic ummah, Western civilisation' (quoted in Keskin 1994). As Çetinsaya (1999) has argued, the Turkists 'gave a special place to Islam in Turkish nationalism' while, particularly following WWI, Islamists too increasingly became supportive of Turkish nationalism. According to Kehl-Bodrogi (2003: 64), nation builders came to conceive the nation as an 'ethnically and culturally homogenous unity. As nation was imagined as Turkish by "race" (1rk) and (Sunni) Islam by religion ... expressions of deviating collective identities, may they be ethnically or religiously determined, were regarded as threats to the nation's unity and treated as separatism'.

Alongside this intertwining with Islam, both the Ottoman and Republican states have had a complex relationship with Alevism. During the Hamidian period Alevism was perceived as heterodox, heretical, deviant or un-Islamic and had become the target of Sunnification/Islamisation policies aimed at creating a majority (Sunni Hanefi) Muslim base for the Ottoman state. As the Committee of Union and Progress (İttihat ve Terakki Cemiyeti, CUP) became more powerful following the 1908 restoration of the constitution, Alevism increasingly became the target of the Turkish nationalists in their Turkification (in practice Muslimisation), or nation-building policies. In this period, the CUP commissioned a number of ethnographic investigations on the characteristics of non-Sunni Muslim communities in Anatolia. A further motivation for these investigations were fears that such communities were coming under the influence of and were the target of Christian missionaries and Armenians. In 1914-1915, investigations on the Alevis conducted by the CUP official Baha Said Bey posited that Alevis were of Turkish origin by drawing links between Alevi practices and central Asian shamanism (Birdoğan 1995). Alevis were rearticulated as 'real Turks' ('öz Türk') that had carried and preserved Turkish customs and traditions, race, blood and language since the pre-Islamic and pre-Ottoman era. This re-imagined Alevi identity was in turn used as element in the construction of Turkish national identity in order to posit an ethnic continuity with Central Asia (Ateş 2012). Under the Republic, the works of Baha Said and the articulation of Alevis as 'real Turks' came to form the basis of nationalist historiography. Consequently, Alevi identity, which was perceived as heretical by the (Sunni) Islamic Ottoman state, became reframed (as seen by the writings of prominent politicians and historians Hasan Reşid Tankut and Fuat Köprülü) 
as constituting a 'Turkish Islam' in contrast to what was described as the 'Arabised Islam' of the Ottoman past (Ateş 2012; Dressler 2013; Massicard 2007).

These policies can be understood through what Brackette Williams (1989) has described as the transformist hegemony of nationalism. This refers to the process whereby a putative homogeneity is created out of heterogeneity through a process of 'appropriations that devalue and deny their link to marginalised others' contributions to the patrimony'. During the construction of Turkish national identity, Alevism was ethnicised and re-articulated in order to appropriate elements of it to create a majority Muslim Turkish bloc. As suggested by Williams' framework, this appropriation did not involve recognition of Alevism but rather marked a process through which it would be rendered obsolete or decapitated. Yet, despite these efforts to absorb Alevis through their reimagining as Muslim Turks, they continued to be regarded as suspect even when they have tried to assimilate into the majority bloc. The one-party regime (1923-1946) of the early Republic, in continuity with the Ottoman state, perceived Kızılbaş Alevis as posing a danger to national unity, for purportedly driving 'real Turks' towards Kurdishness and making them a potential fifth column of Iran. Such attitudes continued and were articulated in the multi-party period in terms of the so-called $3 \mathrm{Ks}-$ Kızılbaş, Kurds (Kürt) and communists (Komünist) - as constituting the key national security threats. Their persistence can be observed in an internal confidential report prepared by the military just before the 1980 coup titled 'Internal Threats aimed at Turkey' where Alevism, defined as comprising a mix of Bektashi Turkish customs and Sunni principles, was designated as an internal threat incited by internal (Kurdish) and external forces (Radikal 11 July 2013). The particular ways in which the PRA as an Islamic authority intervened in these developments is traced below.

\section{The ulama from the Ottoman Empire to the Republic}

As noted above, scholarship on Turkey has predominantly characterised the PRA as an ideological apparatus of the ostensibly secular state, for the purposes of controlling religion, serving as a legitimising mechanism and nationalising Islam (Gözaydın 2009; Kara 2008; Mardin 1982: 171-98). Yet these accounts not only have neglected lines of continuity with the Ottoman ulama but also deny any agency to the PRA. In its heyday, the Sunni ulama in the Ottoman Empire incorporated a wide network of institutions including the office of the Şeyhülislam, comprising judicial and educational responsibilities alongside the muftis (ulama charged with giving Islamic legal judgements known as fatwas), imams, preachers, Sufi sheikhs and waqfs (religious foundations). The extent of the power of the Şeyhülislam in the Islamic Ottoman Empire remains contested. In theory, the Şeyhülislam could contravene the sovereign by refusing to issue a fatwa, but in reality, they were themselves appointees of the sultan. What existed was a symbiotic relationship in which the ulama, as the carriers of Islamic authority, would prop up and protect the rule of sovereigns in return for access to state resources that they could employ in shaping the community.

In addition, the Ottoman ulama played a key role in shaping the boundaries of the ummah (Muslim community) and propagating Sunni Hanefi Islam against the various heterogeneous communities. The emphasis on Sunni orthodoxy has been traced to the rivalry between the Shi'a Safavids of Persia and the Sunni Ottoman state during the sixteenth century (culminating in the Battle of Chaldiran in 1514). For the Ottoman rulers, the Safavids had posed a challenge to the state's claim to be the Caliph of all Muslims and hence Islam's universal authority (Deringil 1990; Gündoğdu and Genç 2013), and hence the struggle between the two sides has been interpreted chiefly as a political rather than a religious struggle (Deringil 2000; Kehl-Bodrogi 2003). After the struggle against the Safavids, the Ottoman state had started to increasingly use the designation Kızılbaş (Alevis) not just against those considered to be pro-Shah loyalists but against all communities regarded as heterodox and the Shi'a that were perceived as open to infiltration by external enemies and missionaries (Ateş 2012; Deringil 2000; Kehl-Bodrogi 2003; Massicard 2007). The Sunni ulama were at the forefront in delineating these communities as a threat to the abode of Islam. In 1548 a fatwa was issued by the Şeyhülislam Ebussuud Efendi in which the Kizılbaş were declared heretics and their killing was proclaimed permissible by Islamic law. Subsequently, such communities became the most persecuted elements under the Ottoman state, whilst 
non- Muslims, considered as the 'people of the book', were recognised and protected under the millet system (Deringil 1993).

In the nineteenth century a renewed focus on Sunni orthodoxy emerged owing to a 'legitimacy crisis' of the Ottoman state resulting from the loss of territories and the rise of nationalism (Deringil 1998). Following the failed attempts to forge a territorially based Ottoman identity - the policy of Ottomanism state ideology under Sultan Abdulhamid II (1876-1909) shifted towards pan-Islamism. This period was marked by the increased propagation of the Sunni Hanefi School of Islamic jurisprudence as the 'official belief' (mezheb-i resmiye). Ateş (2012) has gone further to describe Ottoman modernisation itself as a process of Sunnification, including the outlawing of the Bektashi order following the abolition of the Janissary Corps by Sultan Murad II in 1826. Consequently, in marking the first self-conscious drive to establish a majority Sunni (Hanefi) Muslim social base for the state, this period saw the increasing pursuit of Islamisation policies targeted at communities perceived as potential fifth columns, such as the Yezidi Kurds, Kızılbaș Alevis, Zaidi Shi'a in Yemen and Shi'a communities in the Iraqi provinces (Dressler 2013; Gündoğdu and Genç 2013). In particular, this involved both the active encouragement of conversion and also coercion (Deringil 1998; Gündoğdu and Genç 2013). The Sunni ulama and Sufi sheikhs played a leading role in the propagation of Sunni orthodoxy, through missionary activities and the construction of mosques, whilst Sunni imams tasked with fighting 'heresy' were involved in the state surveillance of the various faith communities (Ateş 2012; Deringil 1993; Gündoğdu and Genç 2013). For instance, reports prepared by the former Şeyhülislam Hüseyin Hüsnü Efendi (related by Deringil 1990: 51) suggest that the ulama not only saw non-Sunni heterodox communities as potential fifth columns to be kept under surveillance but also regarded Islamisation as necessary for the maintenance of order, as the instillation of Sunni Islam in the population would 'accomplish more by education than his illustrious ancestor Selim I did by the sword'.

Alongside the push for Sunnification/Islamisation, the waves of modernisation and centralisation in the Ottoman Empire had resulted in increasing encroachments into the ulama's traditional domain of authority. The ulama nevertheless were partly able to resist such pressures by playing an active role in the implementation and shaping of modernisation reforms and expanding their monopoly over religious life. Yet the secularisation of the legal framework following the establishment of the Republic in 1923 resulted in a considerable narrowing of the ulama's remit. However, rather than marginalising the PRA into a submissive and passive role within the ostensibly secular state, in reality two dynamics resulted in the growing influence and remit of the ulama. The first of these was the absorption of the Ottoman ulama into the body of the PRA. This absorption meant that the PRA, while not a monolithic body, could act as a carrier and preserver of identity and of collective memory and consciousness, endowing with its own sense of mission compared with other state actors. This dynamic can be observed through tracing the continuities in the ulama's approach to the Alevis from the Ottoman Empire to the Republic. The second dynamic was the continued reversion of other state actors, such as the military, to the PRA for the legitimation of policies. Up until the current ruling Islamist AKP ascended to government in 2002, it was in fact periods following military interventions that the PRA's infrastructure and role saw the greatest enlargement. This was critical in creating the Turkey's ulama: between Islam and the nation opportunities and space for the ulama to expand its domain of action and influence over time, which in turn enhanced the ability of the PRA to negotiate the boundaries of the national community. The section below will discuss these two dynamics.

\section{The PRA and Alevis}

\section{The PRA's role as 'carrier and preserver' of Sunni Muslim identity}

Since its inception, the PRA has been characterised, by the institution itself and by scholars, as the representative and propagator of a 'high Islam', cleansed of 'divisive' sectarian rifts and superstition. In general, the PRA has emphasised its authority in relation to alternative faith communities (such as Alevis) and hierarchies (including tariqat orders) on the basis of being 'above' sectarian or denominational divisions, representing itself as the principal authority in providing 'healthy', 'true', 'correct', objective knowledge of a universal Islam that is 'encompassing of all groups'.6 Nevertheless, 
it has also been widely acknowledged that the PRA has a Sunni Hanefi reading of Islam (Doğan 2009; Gözaydın 2014). Indeed, having absorbed the guardians of Sunni Hanefi orthodoxy in the Ottoman Empire, the PRA became a central institutional site and a key carrier and preserver of Sunni Hanefi Muslim identity. This can be clearly observed through tracing the PRA's approach to Alevism.

The PRA's official publications, both those intended for internal and public consumption, are important sources through which to identify this continuity, especially how the ulama define the bounds of Islam and the ummah. What is evident is a double discourse of the ulama in both periods, one that rejects Alevism as heretical and another that seeks to decapitate it through re-articulation within an Islamic framework. Both can be observed in official documentation in the Republican era, the common thread of which suggests that in parallel to the late Ottoman period, the PRA has approached Alevism as separationist or, as sowing factionalism, disunity or sedition against the principle of unity or oneness of god (tawhid). There have been different positions by different state and political actors such as the nationalist historians or the military who were working to re-articulate Alevism as 'Turkish Islam', but prior to 1980 especially, the PRA displayed a more rejectionist stance. Alevism was rejected not only as a false faith but also perceived as being outside Islam. An example of this is a controversial 1948 publication by the PRA, containing a foreword by its former head Ahmet Hamdi Akseki (1947-1951) in which he argues that Shiism and its different formations, such as Batiniyya [including Alevism7], were propagated by Iranian Zoroastrians and Jews to sow sedition within the Islamic community and corrupt it; he declares 'our nation must be protected from falling into the trap of these evil spirited peoples' that are 'corrupting the pure beliefs of our people' (Hammadi 1948: 3). Similarly, negative portrayals of Alevis also include a PRA publication entitled 'Religion and Nationalism' (Din ve Milliyet) printed in 1956 where it is stated that 'to reach the unity that is required by religion, there is a need to prevent the entry of false and Batiniyya sectarian currents' (Kürkçüoğlu, 1956: 17). The PRA's hostility towards Alevism was not unnoticed by others; consider the following observation by American diplomats in 1956; 'this powerful minority [Alevis] has no contact with the official religion. It has no representative at the Direction [sic] of Religious Affairs; to the contrary it is there that it encounters its worst enemies and the Director of Religious Affairs, Mr Eyup Sabri Hayirlioglu, did not hesitate to say to a foreign journalist some time ago that the Alevis follow a false faith' (Bali 2011: 34). The PRA's internal documents suggest that this inimical stance was systemic and resulted in discriminatory practices. For instance, a circular to muftis from the PRA headquarters in 1959 censures imams for refusing to conduct funeral services for Alevis, stating that Alevis should be considered as Muslims (Başbakanlık Cumhuriyet Arşivi (Prime Ministry's Republic Archives, BCA) 1959). Likewise, the former president of the PRA Tayyar Altıkulaç (1978-1986) observes in his memoirs that many PRA personnel held similarly negative views, such as that one should not eat food handled by Alevis (Altıkulaç 2011).

Following the 1980 military coup, there was a renewed emphasis on Islam with respect to Turkish national identity, which occasioned a shift in the PRA's approach towards Alevism towards its rearticulation within an Islamic framing, in contrast to the comparatively more rejectionist stance adopted by members of the ulama. This was a consequence chiefly of the adoption by the junta leaders of the Turkish-Islamic Synthesis (TIS), a policy of Islamization developed by anti-communist, rightistconservative-Islamist intellectuals as a means to ensure national unity following the intense social polarisation and sectarian violence of the late 1970s. Such a turn is evident, for example, in the works of a long-term PRA official Abdulkadir Sezgin8 (Sezgin 1996, 2002, 2012), who published numerous texts (on behalf of the PRA) in the 1990s claiming that Alevis were in reality Hanefi Sunnis. The PRA had been accorded a central role in the implementation of the TIS that involved the expansion of religious infrastructure, education and media.

Yet, even when the PRA began to articulate Alevism within an Islamic framework especially from the 1980s, the ongoing suspicion and depiction of Alevis as a potential fifth column - open to infiltration by Iran, communists and atheists-continued. Alevis were portrayed as impressionable and as coming under the influence of Iranian culture and 'Khomeneism', masons, Christians and atheists (Sezgin 2012 [1990, 1991, 1995]: 270) while being described as the biggest danger and threat after Kurdish currents to 'national unity' (Sezgin 1996). It was the PRA's duty, according to this view, to 'enlighten' Alevis, 
so that they would not be left in 'darkness'(Sezgin 2012 [1990, 1991, 1995]: 269). Likewise, the PRA's head of strategy, Necdet Subaş1 (2006: 49-50), argued that 'emotionally sour' Alevis were being rapidly politicised and could be 'easily incited' by internal and external enemies trying

to ruin 'social unity' and 'harmony'. This precise logic is reflected in the PRA's 2009-2013 Strategic Plan, which identifies as a 'threat' the 'efforts to show different views and interpretations of Islam as a different religion' and 'the demands by some circles to remove compulsory religious education', both of which have been linked with Alevi organisations (PRA 2008: 39). Reflecting such policies the PRA undertook surveillance of Alevi communities comparable to the Ottoman ulama, who were both missionaries pursuing Islamisation and also acted as informants for the state on heterodox and nonSunni communities. This involved religious officials being tasked with observing and informing on Alevis and Alevi currents in the context of state security measures. One example is a circular to muftis from the PRA headquarters dated 1946, where it is stated: 'it has been observed and heard that in some areas some unknown people are making propaganda for particular purposes. Their propaganda especially is against the Hanefi denomination and sometimes against the prophet's hadiths and Sunnah and aimed at forming another denomination and as such is a form of tariqat and therefore illegal ... those that are making propaganda create factionalism amongst the public intentionally and there is no doubt that they are trying to damage national unity that we need more than ever. We must be very sensitive to do this and if we hear or see anything like this, you must immediately inform the presidency' (Başbakanlık Cumhuriyet Arşivi (Prime Ministry's Republic Archives, BCA) 1946). That this surveillance was a systemic and routinized policy towards Alevis is further suggested by other examples. A booklet of regulations circulated to muftis in 1961 for instance contains the warning that 'whatever the intentions, anyone that is seen or heard in confusing our public's minds with thoughts that are against the Sunni denomination and those that spread Shiism and Alevism propaganda by raising events that occurred 1300 years ago, and in this way can become a means for causing damage to national unity, must be reported immediately to the Presidency' (Diyanet İşleri Başkanlığ 1 [PRA] 1961). The continuation of these practices can be observed through the military-sponsored research in the 1990s into religious communities, particularly in regions with large Alevi communities. Prepared as doctoral theses, this research chiefly included data on numerical balances between the different religious communities, as well as information on patterns of worship and levels of observation sourced from PRA officials in mosques.

\section{The PRA and negotiating national identity}

So far the discussion has traced continuities in the ulama's approach towards Alevism. How the PRA negotiates the boundaries of the nation can be observed from the two examples given below.

The first is the PRA's approach to cemevis, Alevi places of worship. As outlined above, the PRA has been persistent in resisting official recognition of cemevis that would give them equal status and the same financial benefits granted to mosques, despite the push for recognition by other state actors, political parties and government authorities. Demands for the recognition of cemevis have instead been portrayed as a threat to Islam, and thereby the nation, and described as separatism. Such a view has been expressed for instance by the former president of the PRA, Tayyar Altıkulaç (2011: 660), who has argued that Alevi leaders 'do not want other pure Alevis to come face to face with the reality of Islam ... that is why you use the issue of the cemevis to distance Alevis from the Islam which is the true religion and Alevism that is within Islam. By presenting cemevis as alternatives to mosques you are being separationist'. Yet, neither have other state actors and political parties such as the AKP been driven by a desire to recognise Alevism outside the framework of Islam. Rather, both sides are concerned with transforming and instrumentalising Alevism through their absorption and consignment to invisibility, for strengthening of the 'majority bloc' - whether the nation or the ummah. In this sense, for both sides, there is a consensus over the hegemonic position of Sunni Muslim Turks within the nation-state. In this light, the PRA's continued resistance can be considered as reflecting the process of 'social closure' and hardening of boundaries facilitated by its position as a key site or reproduction of and carrier of Sunni Islam. 
Such a dynamic can be also observed in a second case, which relates to efforts to establish a Department of Denominations (DoD) whereby Alevism is represented within the PRA. The idea of establishing a DoD has been pursued by various state and political actors since the early 1960s and was in part motivated by the increasing pluralisation of political and social life. Following the transition to multipartism in the late 1940s, restrictions on religious activity were relaxed, and there was an expansion of religious infrastructure including the PRA and religious education, partly motivated by the fight against communism and pressures by the PRA. However, these moves towards greater political pluralism had raised questions not only of how the boundaries of this religious activity would be drawn but also regarding the reappearance of differentiation within the community, which had been regarded by different actors within the state as damaging to national unity. The practice of the Alevifaith had effectively been driven underground through the closure of dervish lodges in 1925 and restrictions on worship and violent campaigns during the one-party era. However, owing to these ongoing concerns over national unity, the propagation of Alevism as 'Turkish Islam' had also gathered new momentum during this period.

This was the context in which the idea of establishing a DoD was originally developed by the military government that took power following the coup d'etat of 27 May 1960. From the content of the meetings held by the junta leaders in late 1960, it can be observed that the establishment of a DoD was conceived largely as an effort to dissolve manifestations of ethnic difference and Kurdish identity through the means of religion (Sunni Islam), as represented by the PRA (Koçak 2010 [1960-1961]). In another words, Sunnification was conceived as a means of Turkification. In one such a meeting, while discussing Kurdish nationalism as being stoked by Russians after WWI,

President Cemal Gürsel9 argued that 'for instance, we regard people that are Alevi as Kurds. The public regard them this way and they, saying "if that is the case", quickly learn Kurdish and become Kurds. Because, for some reason Sunnis see them as enemies. For this reason, Shiis, the Alevi and Bektashis have an inclination to become Kurdish ... Whereas we have to admit that Alevis have continued as the bearers of the original Turkish customs ... If we don't do serious work, teach them the truth and to take possession of this country, it will certainly be a disaster for the future of Turkey' (Koçak 2010 [19601961]). Such differences were regarded as a threat as represented by the response of the Minister of National Defence Fahri Özdilek that, 'there has been insistence on differences between Shii, Shafi'i, Tahtac110 etc. which lead to sectarian separationism [...] it is necessary to put an article in law that abolishes sectarian disputes'. For the junta leaders, these divisions and animosities in the national community could be addressed through policies of Turkification through Islamisation, which would be driven by the PRA as the chief religious authority. According to the Minister of State Hayri Mumcuoğlu, the PRA had 'duties with regards to this matter. We have to establish an Alevi department within the Presidency of Religious Affairs. The Alevis, like the Sunnis will easily separate themselves from Kurdishness once then find a point of authority in the [Presidency] of Religious Affairs' (Koçak 2010 [1960-1961]).

The military's efforts, led by President Cemal Gürsel, to 'Turkify' Alevism by re-articulating it through an Islamic framing subsequently proceeded with legislative efforts to institute a DoD within the PRA, as well as trying to co-opt selected Alevi figures. The first of the legislative efforts was seen just a couple of months later in April 1961, when the idea of a 'Department of Denominations ... to meet the needs of denominations that are included within the Muslim establishment [my emphasis]'(TM 25 April 1961: 231-2) was proposed by the nationalist Republican Villagers Nation Party (Cumhuriyetçi Köylü Millet Partisi, CKMP) during debates on drawing up a new constitution within the Assembly of Representatives. While the proposal itself was rejected without further discussion in the Assembly, it continued to resurface under proposals made by former military members or politicians close to the military leadership. For instance, the establishment of a 'Religious Cultural Matters Directorate' was proposed in January 1962 (MM 28 January 1965 [22 January 1962]) by the permanent members of the Senate (composed chiefly of former members of the junta National Unity Committee General Assembly (27 May 1960-15 October 1961) as well as by the Republican People's Party (Cumhuriyet Halk Partisi, CHP) government around the same time. 
However, while the military actors were seeking to absorb Alevism through Sunnification by the PRA, these efforts further augmented the PRA's ability to negotiate national identity. Both the expansion of the PRA's infrastructure and the recourse of the military to the PRA for Islamic opinion re-enforced its position as an Islamic authority. Consequently, the PRA, supported by conservative- Islamist circles, was able to successfully resist the efforts to establish a DoD despite the drive by the military, one of the Republic's most powerful institutions. The PRA's resistance to the proposal can be inferred from the writings of the Islamist journal Sebilürreşad, which was closely associated with leading PRA ulama and regularly featured their writings. In a 1961 article on the proposal it was argued that there were no 'real Shi'a' in the country and that those 'associating themselves with Shiism' - which they alleged was what the Alevis were doing - were 'extremist and perverted tariqats' steeped in 'superstition', which could not be recognised by a 'laic' state as a 'denomination'. Instead, it was argued that the 'national and religious duty' of the PRA was to 'save these citizens' minds from darkness and enlighten them' (Sebilürreşad 1948: 381-2; Sebilürreşad 1948b: 386-8; Sebilürreşad 1961). Importantly, the theological arguments made by Sebilürreșad against the Alevis were based on the 1948 book on Batiniyya currents published by the PRA (outlined above). Disquiet amongst the ranks of the PRA could also be observed in a 1963 statement made by a group of unnamed preachers referring to themselves as 'Istanbul Vaizleri' (preachers). Again the emphasis was on national-religious unity and the conceptualisation of Alevis as a fifth column of Iran: 'since today in our country there are no denominations that are openly Shii and they don't have a doctrine, it is well placed to ask those that defend Shiism on an individual basis: do they have a book that explains that Shiism's belief, worship and other provisions are against or in line with Ehl-i Sünnet [Sunni Islam] or, by according rights to Shiism in the proposal, are they going to import their books from Iran and in thus re-ignite historical wounds? It is a catastrophe to bring about for no reason Shi'a and Sunni conflict that has been extinguished for centuries, and to divide into two our national and religious unity. The only elements that will benefit from this are foreign ones' (İstanbul Vaizleri 1963). The idea of a DoD was abandoned by 1966 following derogatory statements made against Alevis by the former PRA president İbrahim Elmalı (1965-1966), which was followed by heightened sectarian tension and numerous incidents of violence.

The DoD issue, however, began to regain momentum in the 1990s. During this period there had been an intensification of social conflict, the rise of Kurdish nationalism, the electoral success of Islamist parties and an 'Alevi revival' involving the greater visibility and activism of Alevi organisations. In addition, what followed was the reappearance of narratives - resembling those of the 1950s and 1960s - of Alevis as stalwart allies ofKemalismand as 'real' Turkish Muslims, protecting laicism against radical (Arabised) Islam. While not widely supported by the Alevi movement, it was the 'state friendly' (Shankland 1999: 162) Alevi associations, such as the Cem Foundation that started advocating for Alevi representation in the PRA. The idea of a DoD was also raised by various centre-left parties in parliamentary debates throughout the 1990s and later by the CHP. Most recently, the matter of the DoD emerged as part of the recommendations of the AKP's 'Alevi Opening' (Milliyet 18 November 2010) involving a series of workshops held as part of the broader policy of the government's 'Democratic Opening' policies launched in 2007 to purportedly address problems related to various ethnic and religious groups. With parallels to the efforts of the military to re-articulate Alevism within an Islamic framework, the 'opening' was also heavily criticised by many Alevi organisations as a hidden strategy of assimilation (Radikal 2011). Despite these ongoing attempts, the PRA has maintained its rejectionist stance on the DoD, similar to its rejection of recognition of cemevis. Indeed, the statement by the former PRA president Ali Bardakoğlu in 2001 that a DoDwould be 'completely against the nation-state and society project as aimed for by the will that established the Republic' exemplifies the PRA's stance on the matter (Milliyet 2001).

\section{Conclusion}

The dominant tendency of approaching the Turkish state through the lens of secularism has meant that the role of the PRA has been neglected. This article has argued that the Turkish ulama has been actively negotiating the boundaries of Turkish national identity, particularly with respect to the PRA's approach to Alevism. 
At the same time, as a site of Islam, the case of the PRA raises a key question as to the extent to which there is a tension between Islam (or the ummah) and the nation. The ulama's ongoing resistance to the absorption of Alevism through their recognition and representation within the PRA is suggestive of such a tension. However, given the intertwined nature of Islam and Turkish nationalism, it is not an easy task to determine the extent to which the PRA's agenda can be regarded as an alternative religious agenda, where the ultimate reference is God, as opposed to a nationalist project or a type of religious nationalism. Certainly, Turkish nationalism, as illustrated by the efforts of other institutions such as the military with respect to the Alevis, incorporates multiple, competing and contested narratives. As Verdery (1993: 39) has argued, the nation should be treated 'as a symbol and any given nationalism as having multiple meanings, offered as alternatives and competed over by different groups manoeuvring to capture the symbol's definition and its legitimating effects'. In this sense, within the context of the Turkish nation-state, the PRA may be considered as incorporating one alternative identity project, that of an institution that plays a key role in the reproduction and persistence of Turkish national identity as a Sunni Muslim phenomenon. However, while the PRA references both religion and the Turkish nation and works within the framework of the Turkish nation-state, this does not necessarily mean that they are nationalists, if we understand by the latter that the fundamental point of reference has to be the nation (Brubaker 2012).

In this vein, considering religion and nationalism as analogous but distinct phenomena, the ulama's greater emphasis on Sunni Muslim identity relative to other institutions (such as the military) representing competing political projects still appears to ultimately share an 'overlapping consensus' with other state actors on the vision of establishing a homogenous Sunni Muslim-Turkish political union or nation. Here 'overlapping consensus' is understood in the sense that, while different sides may hold contrasting conceptions of the nation, the same conclusions may still be reached by different actors, and, consequently, 'essential elements of the political conception, its principles, standards and ideals, are theorems... at which the comprehensive doctrines in the consensus intersect or converge' (Rawls 1987). This is facilitated in turn by the 'overlapping systems of meaning' that connect 'self, community, polity, the highest good, the totality' (Lapidus 2001) across religion and nationalism. Within the discourse of the PRA, therefore, the link between (Sunni) Islam and Turkish nationalism is 'reinforced by the symbolic construction of meaning' (ibid), as for example in the framing of the concept of the nation (millet) with Islamic terminology. Consequently, the homogenising impulse of the Turkish nation-state project is one element of the 'overlapping consensus' with the PRA's religious agenda as a carrier of Sunni Muslim identity another. It was this dynamic of appropriation and absorption that underpinned the drive to absorb Alevism by reconstructing it within an Islamic and Turkish (also intertwined with Islam) framing, thereby making it obsolete or decapitating it and ensuring the hegemony of the constructed majority bloc. For the PRA as well as other state actors, Alevis were considered too intertwined with Shiism and Kurdishness and have to be Islamised (and Sunnified) to become Turkish. Any recognition of Alevis outside the Turkish-Islamic framework, whether as Kurds or as non-Muslims, was considered by state actors as posing a danger to the constructed Sunni-MuslimTurkish majority and thereby its dominant position and ownership of the state. Despite these Turkification and Islamisation efforts, Alevis continued to be regarded not just as a heretical other (for Sunni Islam) but as both marginal and suspect, evidenced by their continued surveillance and perceptions of the community as a potential fifth column. The PRA's stance towards Alevism therefore suggests that institutions can become barriers to the hegemonic practices of absorption of nationbuilding thereby impeding the push towards homogeneity. In this manner, the institutionalisation of identities, the very process that ensures the stability of the dominant hegemonic bloc, can over time also harden categories in a way that forms barriers of resistance to absorption of what are perceived as 'marginal elements'. In this sense, institutions may indeed be considered a key factor underpinning the nation as a 'zone of conflict' (Hutchinson 2004).

\section{Endnotes}

1 The designation 'Alevi' is taken here as an "umbrella" (but not necessarily synonymous) term for various heterogonous communities, such as Bektashi and Kızılbaş (Erdemir 2005; Sökefeld 2008; Zırh 2012). 
2 See Erdemir 2005; Sökefeld 2008; Zırh 2012; White 2003. Massicard (2007) has described the Alevi movement as an 'identity movement without an identity'. In addition, Sökefeld has also argued that the master narrative of Alevism employs Sunni Islam as a 'negative template' in order to define itself (Sökefeld 2008).

3 For instance, Turkey has compulsory religious education, which is based exclusively on the Sunni understanding of Islam, while mosques are exempt from paying utility bills.

4 The Hanefi school is one of the four schools of Sunni Islamic jurisprudence alongside Maliki, Shafi'i and Hanbali.

5 Since the establishment of a system of military tutelage following the 1960 coup and until this was challenged during the AKP period (2002-), the military played a fundamental role in shaping the political field and national identity.

6 See for examples Bardakoğlu (2006); PRA 22 January 2014.

7 Used as a pejorative term to refer to various groups condemned by Sunni orthodoxy such as Alevism or Ismailism.

8 Sezgin was based at the PRA for 38 years, and his books were published by the Turkish Religious Foundation (Diyanet Vakf1, DV) and Ministry of Culture throughout the 1990s.

9 Gürsel was appointed by the military following the 27 May 1960 coup and served as president until 1966.

10 This is considered to be an interpretation within Alevism.

\section{References}

Altıkulaç, T. 2011. Zorlukları Aşarken. İstanbul: Ufuk Yayınları.

Asad, T. 1999. 'Religion, nation-state, secularism' in P. Van der Veer,H. Lehmann (eds.), Nation and Religion: Perspectives on Europe and Asia. Princeton; New Jersey: Princeton University Press.

Aspinall, E. 2007. 'From Islamism to nationalism in Aceh, Indonesia', Nations and Nationalism 13, 2: 245-63.

Ateş, K. 2012. Yurttaşlı̆̆ın Kıyısında Aleviler. Ankara: Phoenix Yayınevi.

Bali, R. N. 2011. Revival of Islam in Turkey in the 1950s through the Reports of American Diplomats. Libra.

Bardakoğlu, A. 2006. Religion and Society: New Perspectives from Turkey. Ankara: Publications of Presidency of Religious Affairs.

Barth, F. 1969. Ethnic Groups and Boundaries: The Social Organization of Culture Difference. London: Waveland Press. Bergen: Universitetsforlaget: Allen and Unwin.

Başbakanlık Cumhuriyet Arşivi (Prime Ministry's Republic Archives; BCA). 15 April 1946. F.K:51.0.0.0, Y.No:4.30.14.

Başbakanlık Cumhuriyet Arşivi (Prime Ministry's Republic Archives; BCA). 13 April 1959. K:51.0.0.0, Y.No: 4.33.7.

Bein, A. 2011. Ottoman Ulema, Turkish Republic: Agents of Change and Guardians of Tradition. Stanford; California: Stanford University Press.

Birdoğan, N. 1995. İttihat-Terakki'nin Alevilik Bektaşilik Araştırması (Baha Sait Bey). İstanbul: Berfin Yayınevi.

Bourdieu, P. et al. 1994. 'Rethinking the state: genesis and structure of the bureaucratic field', Sociological Theory 12, 1: 53-75.

Brass, P. R. (ed.) 1985. Ethnic Groups and the State. London: Croom Helm.

Brubaker, R. 2012. 'Religion and nationalism: four approaches', Nations and Nationalism 18, 1: 2-20.

Çağaptay, S. 2006. Islam, secularism and nationalism in modern Turkey: who is a Turk? London: Routledge.

Can, K. and Bora, T. 2004. Devlet, Ocak, Dergâh; 12 Eylül'den 1990’lara Ülkücü Hareket. İstanbul: İletişim.

CCetinsaya, G. 1999. 'Rethinking nationalism and Islam: some preliminary notes on the roots of "Turkish-Islamic synthesis" in modern Turkish political thought', The Muslim World 89, 3-4: 350-76. Conversi, D. 1999. 'Nationalism, boundaries, and violence', Millennium: Journal of International Studies 28, 3: 553-84.

Deringil, S. 1990. 'The struggle against Shiism in Hamidian Iraq: a study in Ottoman counterpropaganda', Die Welt des Islams 30, Nr. 1/4: 45-62. 
Deringil, S. 1993. 'The invention of tradition as public image in the Late Ottoman Empire, 1808 to 1908', Comparative Studies in Society and History 35, 1: 3-29.

Deringil, S. 1998. The Well-Protected Domains: Ideology and the Legitimation of Power in the Ottoman Empire, 1876-1909. London: IB Tauris.

Deringil, S. 2000. "There is no compulsion in religion": on conversion and apostasy in the Late Ottoman Empire: 1839-1856', Comparative Studies in Society and History 42, 3: 547-75.

Diyanet İşleri Başkanlığı [PRA] 1961. Müftü Ve Vaizlerin Irşad Vazifelerini Ifa Ederken Göz Önünde Tutmaları Gereken Hususlar Hakkında Açıklama. Ankara: Diyanet İşleri Başkanlığı Yayınları.

Diyanet İşleri Başkanlığı [PRA] 2008. T.C. Diyanet İşleri Başkanlığı Stratejik Plan (2009-2013). Ankara: Türkiye Diyanet Vakfi.

Doğan, B. 2009. T.C. Diyanet İşleri Başkanlığının Görevleri Bakimindan Yapılması Gereken

Hususlar İle İlgili Güncelleştirilmiş Bir Rapor. Diyanet İşleri Başkanlığı.

Dressler, M. 2013. Writing Religion: The Making of Turkish Alevi Islam. Oxford: Oxford University Press.

Duara, P. 1996. Rescuing History from the Nation: Questioning Narratives of Modern China. Chicago and London: University of Chicago Press.

Erdemir, A. 2005. 'Tradition and modernity: Alevis' ambiguous terms and Turkey's ambivalent subjects", Middle Eastern Studies 41, 6: 937-51.

Göçek, F. M. 1993. 'Ethnic segmentation, western education, and political outcomes: nineteenth century Ottoman society', Poetics Today 14, 3: 507-38.

Gözaydın, İ. 2009. Diyanet, Türkiye Cumhuriyeti'nde Dinin Tanzimi. İletişim Yayınları.

Gözaydın, İ. 2014. 'Management of religion in Turkey: the Diyanet and beyond' in Ö. H. ınar, M.

Yildırım (eds.), Freedom of Religion and Belief in Turkey. Newcastle upon Tyne: Cambridge Scholars Publishing.

Gündoğdu, C. and Genç, V. 2013. Dersim'de Osmanlı Siyaseti. İstanbul: Kitap Yayınevi.

Hammadi, M. M. 1948. Batiniler Ve Karmatilerin İç Yüzü. Ankara: Diyanet İşleri Başkanlığı Yayınları. Hatina, M. (ed.) 2009. Guardians of Faith inModern Times: ulama' in theMiddle East. Leiden: Brill.

Hurriyet Daily News. 2016. 'Legal status to Alevi worship houses a "Red Line," says Turkey's religious body head'.

Hutchinson, J. 2004. Nations as Zones of Conflict. London: Sage.

İstanbul Vaizleri 1963. Diyanet İşleri Başkanlığı Kuruluş ve Görevleri Kanun Tasarısı Hakkında İstanbul Vaizlerinin Görüş ve Tenkidleri. Istanbul.

Jessop, B. 1990. State Theory: Putting the Capitalist State in its Place. Pennsylvania: Penn State Press. Kara, İ. 2008. Cumhuriyet Türkiyesi'nde Bir Mesele Olarak İslam. İstanbul: Dergah Yayınlar1.

Kaufmann, E. 2008. 'The lenses of nationhood: an optical model of identity', Nations and Nationalism 14, 3: 449-77.

Kedourie, E. 1993. Nationalism. Oxford, Cambridge: Blackwell.

Kehl-Bodrogi, K. 2003. 'Atatürk and the Alevis: a holy alliance?' in P. J. White, J. Jongerden (eds.), Turkey's Alevi Enigma: A Comprehensive Overview. Brill: Leiden.

Keskin, M. 1994. 'Ziya Gökalp'in Üç Teklifinin (Türkleşmek, İslamlaşmak, Muasırlaşmak) Türkiye Cumhuriyeti'nde Uygulanmas1', Erciyes Üniversitesi Sosyal Bilimler Enstitüsü Dergisi 5: 69-75.

Kirişci, K. 2000. 'Disaggregating Turkish citizenship and immigration practices', Middle Eastern Studies 36, 3: 1-22.

Koçak, C. 2010. 27 Mayıs Bakanlar Kurulu Tutanakları. Yapı Kredi Yayınları/Tarih.

Kürkçüoğlu, K. E. 1956. Din Ve Milliyet. Diyanet İşleri Reisliği Yayınlar: Ankara.

Lapidus, I. M. 2001. 'Between universalism and particularism: the historical bases of Muslim communal, national, and global identities', Global Networks 1, 1: 37-55.

Mardin, Ş. 1982. 'Turkey: Islam and westernization' in C. Caldarola (ed.), Religions and Societies: Asia and the Middle East. Herndon, Virginia, U.S.A: Walter de Gruyter.

Massicard, E. 2007. Türkiye'den Avrupa'ya Alevi Hareketinin Siyasallaşması. Istanbul: İletişim Yayınevi.

Mihelj, S. 2007. "Faith in nation comes in different guises": modernist versions of religious nationalism', Nations and Nationalism 13, 2: 265-84.

Millet Meclisi Tutanak Dergisi [The Journal of the National Assembly, MM]. 28 January 1965 [22 January 1962]. 
Milliyet. 18 August 2001. 'Alevilerin İbadet Yeri Cami Olmalı'.

Milliyet. 18 November 2010. 'Cemevleri 'Diyanet' Gibi Olacak'.

Özkirimli, U. 2000. Theories of Nationalism: A Critical Introduction. Basingstoke: Palgrave.

Radikal. 11 July 2013. 'Asker, Alevileri İç Tehdit Saymış: “Aleviler Devlete Sızmaya Çalışıyor””.

Radikal. 10 September 2011. 'Kitaptaki Alevilik Için Aleviler Çok Tepkili'.

Rawls, J. 1987. 'The idea of an overlapping consensus', Oxford Journal of Legal Studies 7, 1: 1-25.

Sebilürreşad 1948. 'Batiniler ve Karmatilerin İç Yüzü', Sebilürreşad 1, 24: 381-2.

Sebilürreşad 1948b. “'Gizli', Tarikatlar Nasıl Başladı' 1, 24: 386-8.

Sebilürreşad 1961. 'Diyanet Riyaseti Teşkilatı Tasarısı Kakkında Bazı Mülahazalar', Sebilürreşad 14, 348.

Sezgin, A. 1996. Alevilik Deyince. İstanbul: Burak Yayınevi.

Sezgin, A. 2002. Sosyolojik Açıdan Alevilik-Bektaşilik. Ankara: Yeni Türkiye Yayınları.

Sezgin, A. 2012[1990, 1991, 1995]. Hacı Bektaş Veli ve Bektaşilik. Ankara: Kültür Bakanlığı.

Shankland, D. 1999. Islam and Society in Turkey. Huntingdon, England: Eothen Press.

Sidel, J. T. 2007. "On the "anxiety of incompleteness": a post-structuralist approach to religious violence in Indonesia', South East Asia Research 15, 2: 133-212.

Smith, A. D. 1998. Nationalism and Modernism. London: Routledge.

Smith, A. D. 2003. Chosen Peoples: Sacred Sources of National Identity. Oxford: Oxford University Press.

Sökefeld, M. 2008. Struggling for Recognition: The Alevi Movement in Germany and in Transnational Space. New York: BerghahnBooks.

Subaşı, N. 2006. Diyanet İşleri Başkanlığı Üzerine Laik Bir Cumhuriyet'te Sürdürülebilir Din Politikaları. Muğla Üniversitesi.

Temsilciler Meclisi Tutanak Dergisi [The Journal of the Representatives Assembly, TM]. 25 April 1961.

Van der Veer, P. 1994. Religious Nationalism: Hindus and Muslims in India. Berkeley and Los Angeles, California: University of California Press.

Verdery, K. 1993. 'Whither "nation" and "nationalism"?', Daedalus 122, 3: 37-46.

Williams, B. F. 1989. 'A class act: anthropology and the race to nation across ethnic terrain', Annual Review of Anthropology 18: 401-44.

Wimmer, A. 1997. 'Who owns the state? Understanding ethnic conflict in post-colonial societies', Nations and Nationalism 3, 4: 631-66.

White, P. 2003. 'The debate on the identity of "Alevi Kurds"' in P. J. White, J. Jongerden (eds.), Turkey's Alevi Enigma: A Comprehensive Overview. Brill: Leiden.

Zaman, M. Q. 2010. The Ulama in Contemporary Islam: Custodians of Change. Princeton and Oxford: Princeton University Press.

Zimmer, O. 2003. 'Boundary mechanisms and symbolic resources: towards a process-oriented approach to national identity', Nations and Nationalism 9, 2: 173-93.

Z1rh, B. C. 2012. 'Following the dead beyond the 'nation': a map for transnational Alevi funerary routes from Europe to Turkey', Ethnic and Racial Studies 35, 10: 1758-74.

Zubaida, S. 1993. Islam, the People and the State. London: Tauris.

Zubaida, S. 2004. 'Islam and Nationalism: Continuities and Contradictions', Nations and Nationalism 10, 4: 407-20. 